\title{
Article \\ Studies Regarding the Antibacterial Effect of Plant Extracts Obtained from Epilobium parviflorum Schreb
}

\author{
Erdogan Elvis Șachir ${ }^{1, *,+}$, Cristina Gabriela Pușcașu 1,*,+®D, Aureliana Caraiane ${ }^{1,+}$, Gheorghe Raftu 1,t \\ Florin Ciprian Badea ${ }^{1,+}$, Mihaela Mociu ${ }^{1,+}$, Claudia Maria Albu ${ }^{1,+}$, Liliana Sachelarie ${ }^{2, *}+\mathbb{D}_{\text {, }}$ \\ Loredana Liliana Hurjui ${ }^{3, *,+}$ (D) and Cristina Bartok-Nicolae ${ }^{1, *,+}$ (iD
}

check for updates

Citation: Șachir, E.E.; Pușcașu, C.G. Caraiane, A.; Raftu, G.; Badea, F.C.; Mociu, M.; Albu, C.M.; Sachelarie, L.; Hurjui, L.L.; Bartok-Nicolae, C. Studies Regarding the Antibacterial Effect of Plant Extracts Obtained from Epilobium parviflorum Schreb Appl. Sci. 2022, 12, 2751. https:// doi.org/10.3390/app12052751

Academic Editor: Ionel Calin Jianu

Received: 2 February 2022

Accepted: 3 March 2022

Published: 7 March 2022

Publisher's Note: MDPI stays neutral with regard to jurisdictional claims in published maps and institutional affiliations.

Copyright: (C) 2022 by the authors. Licensee MDPI, Basel, Switzerland. This article is an open access article distributed under the terms and conditions of the Creative Commons Attribution (CC BY) license (https:// creativecommons.org/licenses/by/ $4.0 /)$.
1 Department of Dentistry, Faculty of Dentistry, “Ovidius” University of Constanta, 900527 Constanta, Romania; drcaraiane@yahoo.com (A.C.); gheorgheraftu@yahoo.com (G.R.); florinb.md@gmail.com (F.C.B.); mihaelabacula@gmail.com (M.M.); albumariaclaudia@yahoo.com (C.M.A.)

2 Department of Biopysics, Faculty of Dentistry, Apollonia University, 700511 Iasi, Romania

3 Faculty of Dentistry, Grigore T. Popa University of Medicine and Pharmacy, 700115 Iasi, Romania

* Correspondence: erdogan_sachir@yahoo.com (E.E.Ș.); cristinap@gmb.ro (C.G.P.); lisachero@yahoo.com (L.S.); loredana.hurjui@umfiasi.ro (L.L.H.); dr.cristina_nicolae@yahoo.com (C.B.-N.); Tel.: +40-74-507-4720 (C.B.-N.)

+ These authors contributed equally to this work.
Abstract: The present study was carried out to develop an experimental endodontic irrigant solution based on plant extracts obtained from Epilobium parviflorum Schreb. that largely replenish the properties of the usual antiseptics used in dentistry. Background: This study investigated the phytochemical contents of plant extracts obtained from Epilobium parviflorum Schreb. and their potential antibacterial activity. Methods: Identification and quantification of biologically active compounds were made by UV field photo spectrometry, adapting the Folin-Ciocalteu test method. Antibacterial activity was tested on pathological bacterial cultures collected from tooth with endodontic infections using a modified Kirby-Bauer diffuse metric method. Results: Polyphenols and flavonoids were present in all plant extracts; the hydroalcoholic extract had the highest amount of polyphenols-17.44 pyrogallol equivalent (Eq Pir)/mL and flavonoids-3.13 quercetin equivalent (Eq Qr)/mL. Plant extracts had antibacterial activity among the tested bacterial species with the following inhibition diameter: White Staphylococcus (16.5 mm), Streptococcus mitis (25 mm), Streptococcus sanguis (27 mm), Enterococcus faecalis $(10 \mathrm{~mm})$. Conclusions: All plant extracts contain polyphenols and flavonoids; the antibacterial activity was in direct ratio with the amount of the bioactive compounds.

Keywords: antibacterial activity; Epilobium parviflorum Schreb.; flavonoids; phenols; vegetable extract

\section{Introduction}

Epilobium is a genus of perennial herbaceous plant (Onagraceae family). The most common species include Epilobium parviflorum Schreb., Epilobium hirsutum, Epilobium rosmarinifolium (Epilobium dodonaei Vill.), Epilobium roseum Schreb. and Epilobium angustifolium [1].

The anti-inflammatory and antiproliferative activity of Epilobium parviflorum Schreb. extracts was initially studied on cells in the context of benign prostatic hyperplasia; the analgesic, antioxidant, antibacterial and antifungal actions were studied in parallel [2-4]. Plant polyphenols represent a group of chemical substances ubiquitously distributed in all higher plants. These secondary metabolites possess free radical scavenging and antibacterial activity. These properties can be advantageously exploited, especially because of the abundance of polyphenols and their derivatives in various agricultural and food industry waste and by-products, and the possibility of convenient extraction by either organic or aqueous solvents [5-7].

In the oral cavity, nearly 700 species of bacteria can be found, including most of Firmicutes, Bacteroidetes, Actinobacteria and Proteobacteria [8]. There are two types of root canal infections: primary and secondary, each with specific microbiology. The primary infection 
results from colonization with a heterogenous group of microbes that have entered the pulp tissue, when exposed during caries or traumas; this group is dominated by Gram-negative oral anaerobic bacteria (Prevotella species, Porphyromonas species, Fusobacterium species, Veillonella species), aside from bacterial species which are also part of the commensal oral microflora: Gram-positive anaerobic bacteria (Propionibacterium species, Bifidobacterium species, anaerobic streptococci), treponemas or Campylobacter species [8,9]. The secondary infection appears inside the root canal system, after the treatment of the affected tooth has been initiated and harbor a limited number of bacterial species, with predominance of Gram-positive bacteria, namely Enterococcus faecalis (E. faecalis), oral streptococci, lactobacilli or Candida albicans; in contrast, Gram-negative bacteria are involved to a lesser extent [10]. The most common microorganism found in asymptomatic, persistent endodontic infections is E. faecalis. Its incidence in this type of infection varies from $24 \%$ to $77 \%$ [8,10]. E. faecalis possesses enzymes and constitutive structures that are able to suppress the action of lymphocytes and promote inflammation, which contributes to progression of endodontic infections $[10,11]$. Also, this microorganism has the ability to attach to dentin due to an inner component which is the collagen-binding protein $[9,11,12]$.

Several studies have evaluated the antimicrobial efficacy of endodontic irrigants such as sodium hypochlorite $(\mathrm{NaOCl})$, ethylene diamine tetra acetic acid (EDTA) and chlorhexidine (CHX) against $E$. faecalis biofilms [13]. In general, the aim of any disinfection strategy is to reduce the bacterial load to a subcritical level so that the patient's immune response allows healing by itself [14]. Endodontic research has always been focused on developing methods or endodontic irrigants that can completely remove the bacterial biofilm with minimal side-effects. Various endodontic irrigants are being widely used in the treatment of biofilms with varied effectiveness. Although $2 \% \mathrm{CHX}$ has been proven to possess a high antimicrobial property, it has failed to disrupt the biofilm. $\mathrm{NaOCl}$ can disrupt the biofilm, disintegrating the dental pulp which is a built-in organ, but it is a well-known irritant to periapical tissues. Therefore, identification of natural products in the disinfection of root canals can be interesting $[13,15,16]$.

In unconventional modern practice, endodontists seek the use of natural remedies as an adjunct to classical therapy, especially since the antibacterial action of plant extracts meets the phenomenon of antibiotic resistance, a problem that dominated medical practice in the second millennium and which seems to persist in an upward trend in the third millennium [17].

Plant extracts are fluid, soft or dry pharmaceutical/phytopharmaceutical preparations obtained by extracting plant products with different solvents [18].

In recent years, emphasis has been placed on the pharmaceutical and therapeutic revaluation of herbal preparations through a good knowledge of the physio-chemical and therapeutic properties of the active ingredients in medicinal plants and the development of extraction techniques and quality control means. Extractive solutions are pharmaceutical forms that contain smaller or larger proportions of active substances together with less active ones and ballast, extracted with the help of solvents. The extraction process involves the separation of the medically active portions of the plant tissues from the inactive or inert components by the use of selective solvents in standardized procedures [19].

Aqueous extractive solutions are prepared from different parts of the plant or mixtures of medicinal plants, using water as a solvent, preferably distilled or softened [20]. Description of the double maceration technique: the extracted product is first mixed with $1 / 2-2 / 3$ of the total amount of solvent, after which the liquid is separated and the residue is pressed. It will contact the rest of the solvent, thus obtaining a new amount of extractive solution. The two extractive liquids will combine and filter after a 24-h rest [21].

Ultrasound-assisted extraction (UAE) is one of the most important techniques used for the extraction of valuable compounds from plant materials and is quite adaptable in the laboratory or on an industrial scale $[22,23]$. The method involves the use of ultrasound, with frequencies ranging from $20 \mathrm{kHz}$ to $2000 \mathrm{kHz}$, which increase the permeability of cell walls and produce cell lysis, thus promoting the extraction of biologically active compounds [24]. 
The aim of the study is the use of plant extracts, obtained from Epilobium parviflorum Schreb., as a basis for alternative therapy in perspective in the treatment of endodontic pathology.

There were two distinct objectives of this study:

(1) Identification and quantification of phenols and flavonoids from the vegetable extracts obtained from Epilobium parviflorum Schreb.;

(2) Testing the antibacterial activity of the vegetable extracts.

\section{Materials and Methods}

\subsection{Harvesting the Plant and Obtaining the Extracts}

Plants were picked during the summer period from rural region of Dobrogea area and left to dry for one month. In the technological process, a drying yield of $20 \%$ was used.

In order to obtain an increased concentration of polyphenols in the aqueous extract, a double maceration extraction technique was used according to the European Pharmacopoeia (2016) [25].

To obtain the hydroalcoholic extract, in a borosilicate container, $50 \mathrm{~g}$ of dried Epilobium parviflorum Schreb. were added to $100 \mathrm{~mL}$ of $95 \%$ ethanol and $100 \mathrm{~mL}$ distilled water, then stored at room temperature for 7 days.

To obtain the ultrasonicated hydroalcoholic extract, in a borosilicate container, $50 \mathrm{~g}$ of Epilobium parviflorum Schreb. plant extract, $100 \mathrm{~mL}$ of double-distilled water and $100 \mathrm{~mL}$ of absolute ethyl alcohol were placed in a glass container; then it was placed in an ultrasonic bath $(30,000 \mathrm{~Hz})$ for $10 \mathrm{~min}$ a day, over 5 days.

The hydroalcoholic plant extracts were placed in a rotary evaporator (IKA-RV 10 digital $\mathrm{V}$, Staufen Baden-Wurtemberg, Germany) to evaporate the solvent, at temperatures lower than $40^{\circ} \mathrm{C}$ and under reduced pressure. Finally, the remaining ethanol was evaporated, placing the flask on the kiln drier until obtaining a consistent weight (three days) [26]. In order to remove the microorganisms from the vegetable extract and to obtain a sterile product, a $0.22 \mu \mathrm{m}$ filter membrane was used, according to the specialized data from the European Pharmacopoeia-Sterility Control (2016), mounted on the vacuum filtration system. Both the filter membrane and the filtration system were mounted together and then autoclaved. To verify the absence of microorganisms in the obtained extracts, a sterility test was performed by the cultivation method, according to European Pharmacopoeia (9th ed, harmonized, Chapter 2.VI.1 Sterility, 2016). Sterility testing method: $10 \mathrm{~mL}$ samples were taken aseptically and transferred to $100 \mathrm{~mL}$ liquid medium (Bio-Merieux, Craponne, France); 3 replicates/type of environment were tested (to promote the development of aerobic and anaerobic microorganisms). The result came as a sterile sample; all test samples tested showed absent microbial growth, as well as the associated negative controls [25].

\subsection{Identification and Quantification of Biologically Active Compounds}

Ethanol as a solvent extraction in analytical grade was obtained from Merck in Darmstadt, Germany; pyrogallol and quercetin were obtained from Sigma-Aldrich Co. (St. Louis, MO, USA).

The Folin-Ciocalteu test method is the simplest method available for measuring the phenolic content of organic products [27]. The basic mechanism is an oxidation/reduction reaction, with the phenolic group being oxidized and the reduction of the metal ion [28]. The principle of the method is based on the reaction between Folin-Ciocalteu reagent and phosphomolybdic acid with the phenolic compounds in the sample, resulting in a mixture of blue oxides [29]. The spectrophotometric measurements were performed with a Specord M400 spectrophotometer, Carl Zeiss, Yena, Germany, using a $1 \mathrm{~cm}$ quartz cell.

\subsection{Bacteriological Tests}

\section{- $\quad$ Study group}

A prospective study was conducted in Constanța, on 60 adults, who required endodontic therapy, in the Endodontics Department of Dentistry Faculty, "Ovidius" University of Constanța. Ethical approval for the study was obtained from the Bioethic's committee of 
Ovidius University 15547/09.11.2018. The study was conducted following the Helsinki declaration that was revised in 2013. Evaluation took place for two years, started on December 2018 and finished on November 2020. All patients with posterior teeth diagnosed with pulp necrosis (i.e., negative response to pulp sensitivity test with cold stimulus, confirmed by absence of bleeding during access cavity preparation), asymptomatic or symptomatic apical periodontitis were considered eligible and included in the study group after providing signed informed consent for the research. All personal data collected from the subject were blinded and stored with the given unique registration number.

The inclusion criteria in the study were: participants had to be over 18 years of age without allergic reactions with posterior teeth diagnosed with pulp necrosis. Moreover, the included teeth also had either symptomatic apical periodontitis, asymptomatic apical periodontitis or chronic apical abscess associated with a periapical radiolucency; absence of root fracture of the involved tooth, absence of periodontal pocket. The exclusion criteria from the study were: patients who are unable to appear for periodic check-ups, teeth with simple decay, teeth with hyperemia, poor oral hygiene, absence of enough tooth structure for rubber dam isolation, patients with the contributory medical history, patients who received antibiotic therapy during the previous 6 months.

At the beginning of the study, 60 patients with asymptomatic or symptomatic apical periodontitis were examined; only 40 of them were accepted for inclusion in the study based on acceptance criteria.

- Harvesting pathological products

The pathological product, infected dentin, was harvested using a sterile Kerr file (20 ISO, Dentsply Sirona), which was then placed in a container with culture medium (Bio-Merieux, France) and transported to the Microbiology Laboratory of the Faculty of Dentistry of the "Ovidius" University of Constanța. The products were seeded on culture medium (Columbia agar $+5 \%$ sheep blood, Bio-Merieux, Craponne, France) which were then thermostated at $37^{\circ} \mathrm{C}$ for $24 \mathrm{~h}$ (Figure 1a,b).
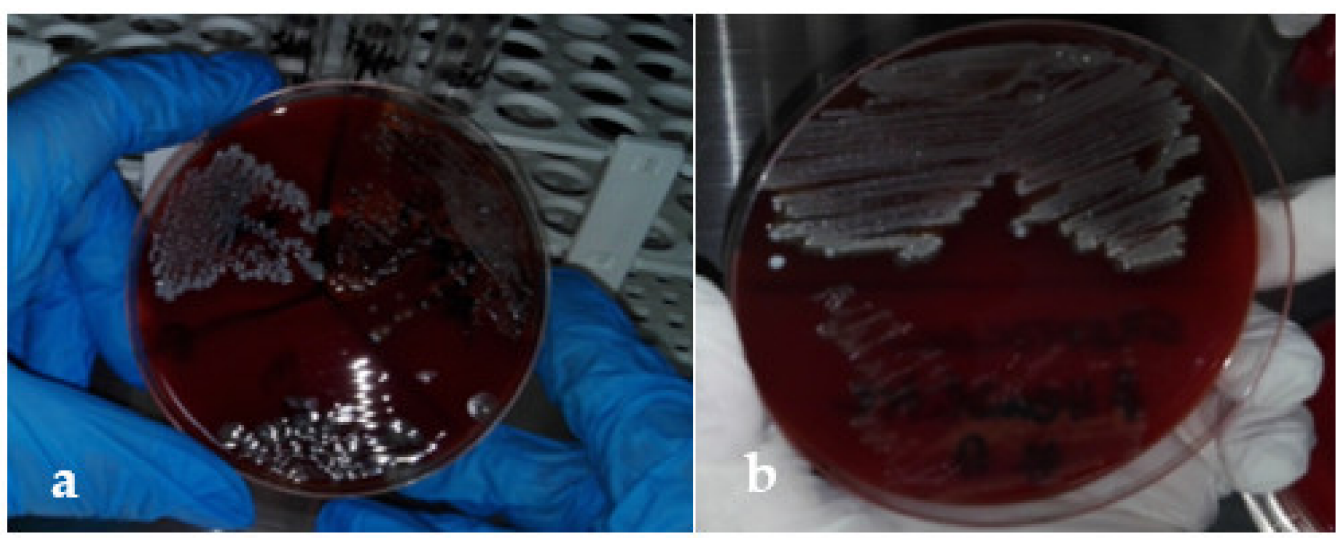

Figure 1. (a,b) - Bacterial cultures developed from pathological products after thermostating at $37^{\circ} \mathrm{C}$ for $24 \mathrm{~h}$.

- Bacteriological identification technique

After seeding on culture media and thermostating, bacterial identification was made using the API (Bio-Merieux, Craponne, France) method (Figure 2a,b). 


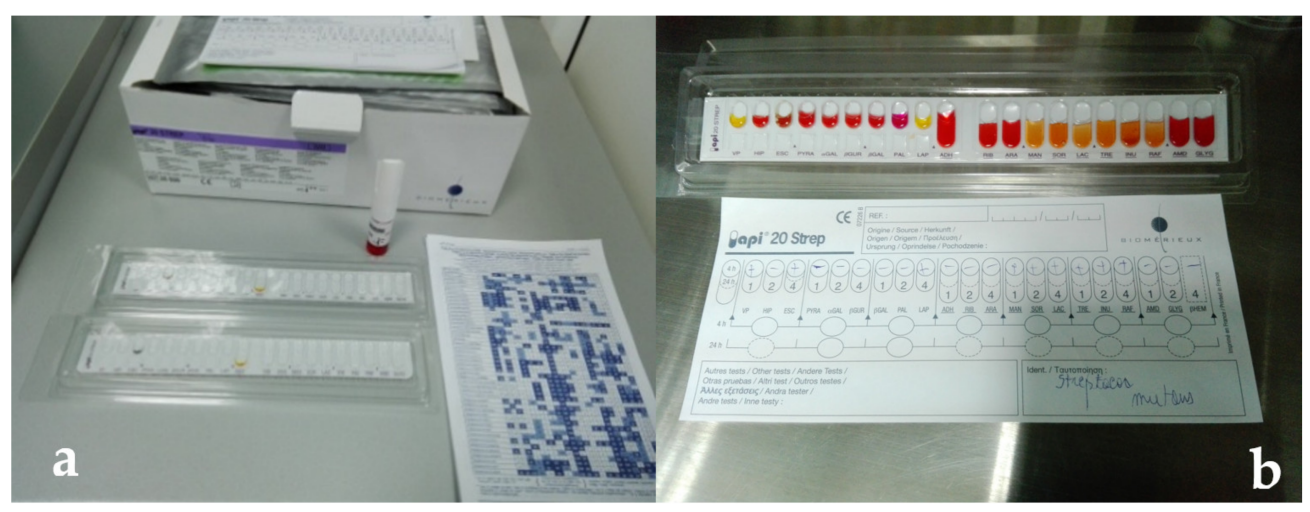

Figure 2. (a,b) API kit (Bio-Merieux, Craponne, France) for the identification of bacterial cultures.

Among the bacterial species, identified from the pathological products taken, are: White Staphylococcus, Streptococcus mitis, Streptococcus sanguis, Enterococcus faecalis and Escherichia coli (Figures 3 and 4).

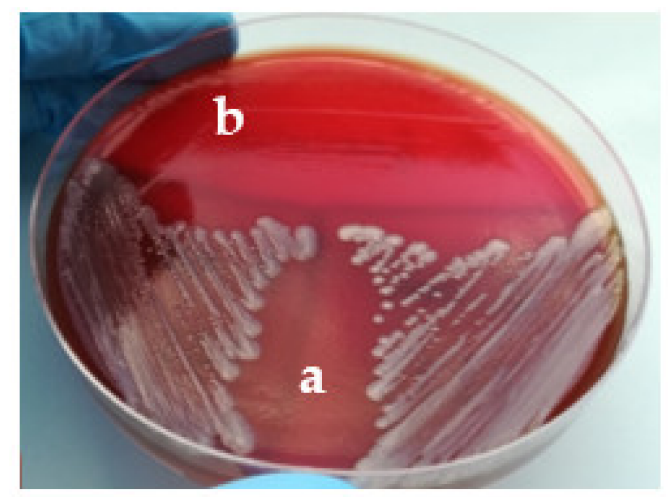

Figure 3. Bacterial cultures, (a) Escherichia coli; (b) Enterococcus faecalis.

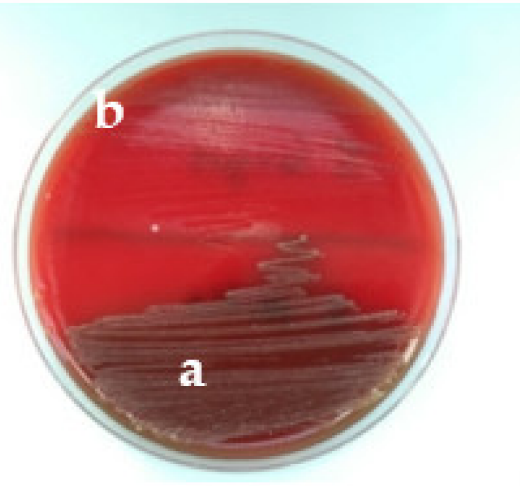

Figure 4. Bacterial cultures, (a) Streptococcus mitis; (b) Streptococcus sanguis.

- Antibacterial effect testing technique of the vegetable extracts

The antibacterial properties were tested on the following bacterial species: White Staphylococcus, Streptococcus mitis, Streptococcus sanguis, Escherichia coli, Enterococcus faecalis. They were sown in Mueller-Hinton and Columbia culture medium (Bio-Merieux, Craponne, France). The bacterial suspension used corresponded to a concentration of $10^{7}$ colonies per training unit/mL micro-test, which correspond to a turbidity of the 0.5 Mac Farland tube (Figures 5 and 6) [30]. 


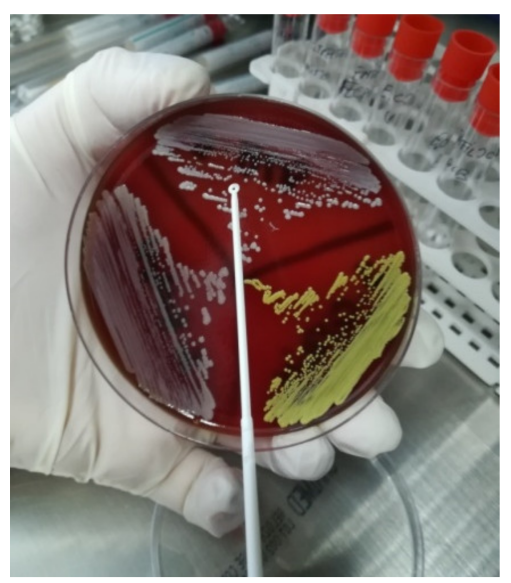

Figure 5. Sampling of bacterial colonies for later introduction into isotonic chloride suspension.

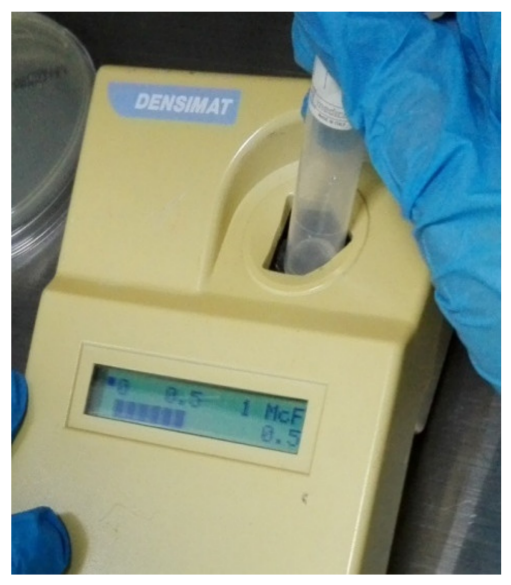

Figure 6. Measurement of the turbidity of the sodium microorganism suspension solution.

The Kirby-Bauer test for antibiotic susceptibility, known as the disc diffusion test, is a standard that has been used for years. This test determines the sensitivity or resistance of bacterial strains to antibiotics. The principle of the method relies on the direct proportionality relationship between the level of sensitivity and the size of the inhibition area of germs colonies developed around the tested substance. Bacterial sensitivity test was realized by adapting the Kirby-Bauer diffusion method in accordance with the protocol described by Romanian Microbiology Society in the Clinical microbiology guide (2017) [31,32].

The method's adaptation consisted of replacing the antibiotic discs with sterile filter paper discs, with the same size as those used in antibiograms; the discs were saturated with $50 \mu \mathrm{L}$ of the test solution. These discs were applied on the culture medium previously seeded with the bacterial strains to be tested (Figure 7); the incubation time was $24 \mathrm{~h}$ at $37^{\circ} \mathrm{C}$. For comparison, similar to the test solutions we applied filter paper discs impregnated with commercial irrigants used in the practice of endodontics $\mathrm{NaOCl} 5.25 \%$ (Cerkamed, Stalowa Wola, Poland) and CHX 2\% (Cerkamed, Stalowa Wola, Poland) on the surface of the sown medium (Figure 8).

\subsection{Statistical Analysis}

The values in the figures are expressed as mean \pm standard error (SEM) of three independent experiments. When required, data sets were examined by one-way analysis of variance (ANOVA) and Dunnett's test as post analysis. A $p$-value less than 0.05 was considered statistically significant. 


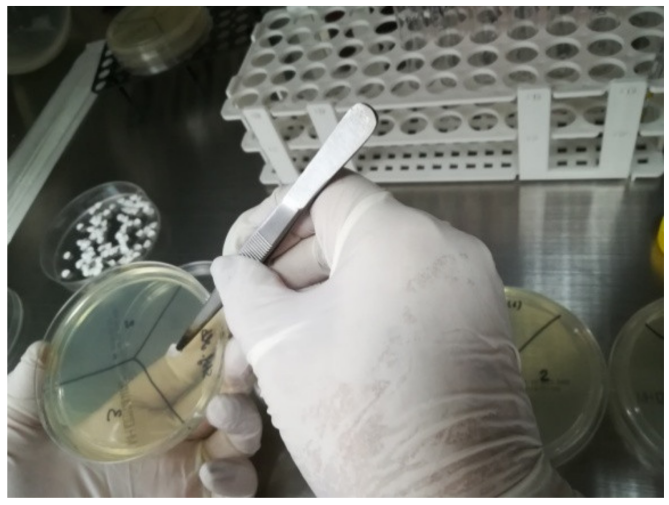

Figure 7. Applying the filter paper disc saturated with $50 \mu \mathrm{L}$ of the test solution.

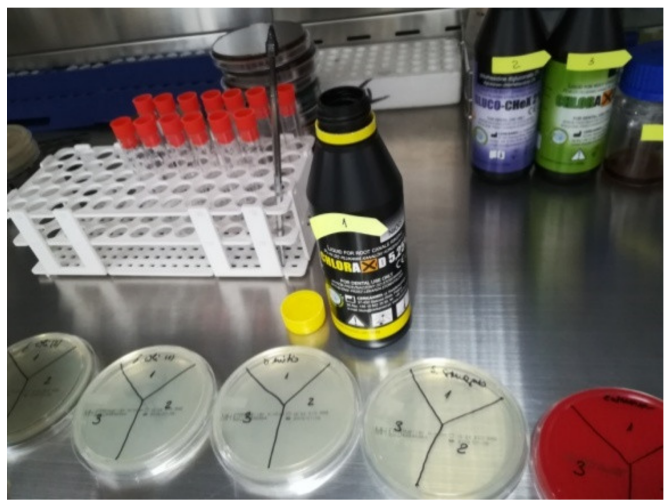

Figure 8. Commercial endodontic irrigants.

\section{Results}

\subsection{Quantification of Total polyphenols in the Three Types of Plant Extracts}

The linear regression equation was calculated and a good linear relationship was obtained between the standard concentrations $(0.05-5 \mathrm{mg} / \mathrm{mL})$ and the absorption at $760 \mathrm{~nm}$ of the reaction solution (Table 1), using as standard pyrogallol calibration. The total polyphenol content of the extracts was expressed as pyrogallol equivalent (EqPir) in the calibration curve (Scheme 1).

Table 1. Pyrogallol standard.

\begin{tabular}{cc}
\hline $\begin{array}{c}\text { Concentration } \\
\mathbf{m g} / \mathbf{m L}\end{array}$ & $\begin{array}{c}\text { Absorbance } \\
\text { at } 760 \mathbf{~ n m}\end{array}$ \\
\hline 5.00 & 3.6022 \\
2.5 & 2.1865 \\
1.00 & 1.2698 \\
0.5 & 0.9899 \\
0.1 & 0.6654 \\
0.05 & 0.4049 \\
\hline
\end{tabular}

Table 2 presents the total phenolic content of the hydroalcoholic plant extract obtained from Epilobium parviflorum Schreb. which was determined from the regression equation (Scheme 1) of the calibration curve, ranging from 17.27 to $17.56 \mathrm{mg}$ EqPir/g plant powder with an arithmetic mean of $17.44 \mathrm{mg}$ EqPir/g vegetable powder; the total phenolic content of the ultrasonicated hydroalcoholic plant extract was determined from the regression equation of the calibration curve (Scheme 1), ranging from 16.90 to $17.15 \mathrm{mg}$ EqPir/g vegetable powder with an average arithmetic mean of $17.05 \mathrm{mg}$ EqPir/g vegetable powder; the total phenolic content of the aqueous plant extract was determined from 
the regression equation (Scheme 1) of the calibration curve, ranging from 5.62 to $5.65 \mathrm{mg}$ EqPir/g plant powder with an arithmetic mean of $5.63 \mathrm{mg}$ EqPir/g vegetable powder (Table 2). The highest polyphenol content was the hydroalcoholic plant extract with a mean of $17.44 \mathrm{Eq} \mathrm{Pir} / \mathrm{mL}$; at the opposite pole, the lowest polyphenol content was the aqueous plant extract with a mean of $5.63 \mathrm{Eq}$ Pir $/ \mathrm{mL}$.

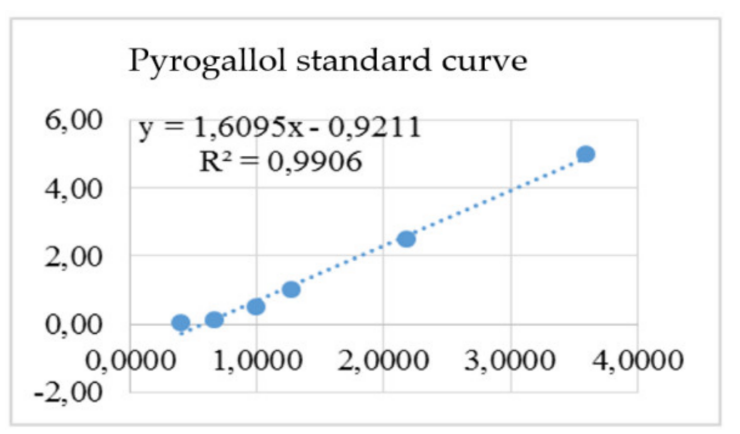

Scheme 1. Calibration curve for the pyrogallol standard.

Table 2. Results of determinations in Eq Pir/mL of total polyphenol content.

\begin{tabular}{cccc}
\hline Vegetable Extract & Determinations No. & Absorbance & EqPir/mL \\
\hline & 1 & 1.6459 & 17.27 \\
Hydroalcoholic & 2 & 1.6635 & 17.56 \\
& 3 & 1.6589 & 17.48 \\
\cline { 2 - 4 } & & Mean/SD & $17.44 \pm 0.14$ \\
\hline \multirow{2}{*}{ Ultrasonicated } & 1 & 1.6349 & 17.10 \\
hydroalcoholic & 2 & 1.6381 & 17.15 \\
& 3 & 1.6225 & 16.90 \\
\cline { 2 - 4 } & & Mean/SD & $17.05 \pm 0.13$ \\
\hline Aqueous & 1 & 0.9236 & 5.65 \\
& 2 & 0.9218 & 5.62 \\
& 3 & 0.9220 & 5.62 \\
\hline
\end{tabular}

$\overline{\mathrm{SD}}=$ Standard deviation

\subsection{Quantification of Total Flavonoids}

The linear regression equation was calculated and a good linear relationship was obtained between the standard concentrations $(0.05-5 \mathrm{mg} / \mathrm{mL})$ and the absorption of the reaction solution at $750 \mathrm{~nm}$ (Table 3), using as standard quercetin calibration. The total flavonoid content of the extracts was expressed as quercetin equivalent (EqQr) in the calibration curve (Scheme 2).

Table 3. Quercetin standard.

\begin{tabular}{cc}
\hline $\begin{array}{c}\text { Concentration } \\
\mathbf{m g} / \mathbf{m L}\end{array}$ & $\begin{array}{c}\text { Absorbance } \\
\text { at } 760 \mathbf{~ n m}\end{array}$ \\
5 & 3.1443 \\
2.5 & 1.6345 \\
1 & 0.8510 \\
0.5 & 0.4407 \\
0.05 & 0.1307 \\
\hline
\end{tabular}




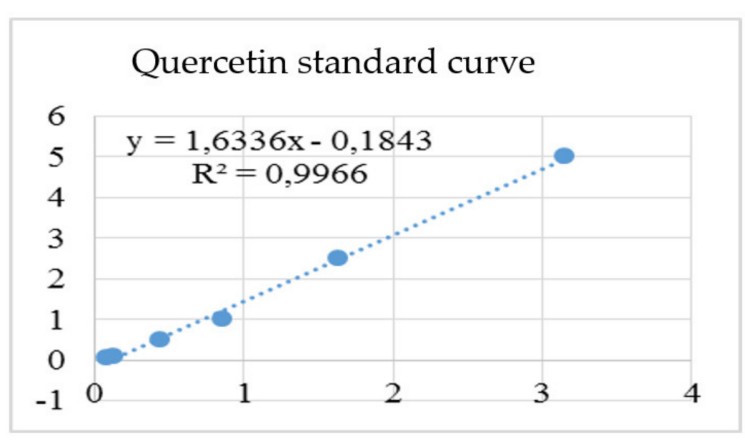

Scheme 2. Calibration curve for the quercetin standard.

As there are no significant differences in the total phenol content between the hydroalcoholic plant extract and the ultrasonicated hydroalcoholic extract, it was decided to determine the total flavonoid content only for the hydroalcoholic extract.

Table 4 presents the total flavonoid content of the hydroalcoholic plant extract obtained from Epilobium parviflorum Schreb. which was determined from the regression equation (Scheme 2) of the calibration curve, ranging from 2.84 to $2.9 \mathrm{mg}$ EqQr/g plant powder with an arithmetic mean of $2.87 \mathrm{mg}$ EqQr/g vegetable powder; the content of the aqueous plant extract was determined from the regression equation (Scheme 2) of the calibration curve, ranging from 0.78 to $0.9 \mathrm{mg}$ EqQr/g plant powder with an arithmetic mean of $0.86 \mathrm{mg}$ EqQr/g vegetable powder. The hydroalcoholic plant extract had the highest flavonoid content with a mean of $2.87 \mathrm{Eq} \mathrm{Qr} / \mathrm{mL}$, and the aqueous plant extract had the lowest level with a mean of $0.86 \mathrm{Eq} \mathrm{Qr} / \mathrm{mL}$.

Table 4. Results of determinations in $\mathrm{Eq} \mathrm{Qr} / \mathrm{mL}$ of total flavonoid content.

\begin{tabular}{cccc}
\hline Vegetable Extract & Determinations No. & Absorbance & EqQr/mL \\
\hline \multirow{3}{*}{ Hydroalcoholic } & 1 & 2.3569 & 2.87 \\
& 2 & 2.3411 & 2.84 \\
& 3 & 2.3779 & 2.90 \\
\cline { 2 - 4 } & & Mean/SD & $2.87 \pm 0.02$ \\
\hline \multirow{2}{*}{ Aqueous } & 1 & 1.1332 & 0.9 \\
& 2 & 1.0619 & 0.78 \\
& 3 & 1.1341 & 0.9 \\
\hline
\end{tabular}

SD = Standard deviation

\subsection{Test Results for Antibacterial Activity of Plant Extracts}

The aqueous solution lacks antibacterial activity on White Staphylococcus, while the two hydroalcoholic plant extracts have an antibacterial effect proportional to the concentration of phenolic compounds. The same aspect was identified on other tested bacterial species, Enterococcus faecalis, Streptococcus mitis, Streptococcus sanguis and Escherichia coli, respectively; the diameter of the areas of inhibition expressed in $\mathrm{mm}$ for the above-mentioned bacterial species tested are given in Table 5.

As can be seen in Scheme 3, the aqueous plant extract has no antibacterial action on any of the tested strains; on the Escherichia coli strain, none of the plant extracts have antibacterial action. On the rest of the tested strains, the antibacterial action is in direct proportionality to the concentration of total polyphenols from the hydroalcoholic plant extracts. 
Table 5. Diameters of inhibition areas expressed in $\mathrm{mm}$.

\begin{tabular}{cccccc}
\hline $\begin{array}{c}\text { Vegetable } \\
\text { Extract }\end{array}$ & $\begin{array}{c}\text { White } \\
\text { Staphylococcus }\end{array}$ & $\begin{array}{c}\text { Streptococcus } \\
\text { mitis }\end{array}$ & $\begin{array}{c}\text { Streptococcus } \\
\text { sanguis }\end{array}$ & $\begin{array}{c}\text { Enterococcus } \\
\text { faecalis }\end{array}$ & $\begin{array}{c}\text { Escherichia } \\
\text { coli }\end{array}$ \\
\hline \multirow{3}{*}{ Hydroalcoholic } & 18 & 26.5 & 25.5 & 11.5 & 0 \\
& 20 & 26 & 26 & 12 & 0 \\
\hline Ultrasonicated & 19 & 25.5 & 26.5 & 26.5 & 0 \\
hydroalcoholic & 16 & 25.5 & 27 & 9.5 & 0 \\
& 17 & 25 & 27.5 & 10.5 & 0 \\
\hline
\end{tabular}

Aqueous

Lacks antibacterial activity on all strains tested

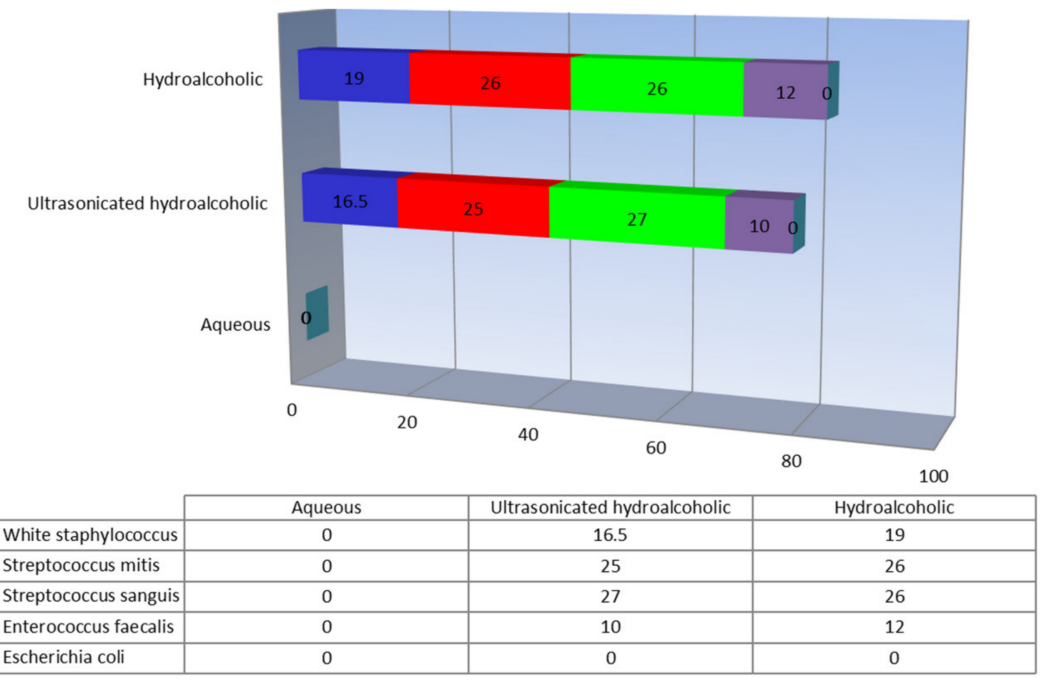

Scheme 3. Inhibition areas in mm of plant extracts.

\subsection{Correlations between Biologically Active Compounds and the Antibacterial Effect}

As can be seen in Table 6 there is a direct proportionality between the total content of biologically active compounds (polyphenols and flavonoids) in the hydroalcoholic plant extract and the antibacterial action on White Staphylococcus; the statistical study shows that there is a high correlation between the two parameters, expressed by a Pearson correlation index of 0.998 . The same aspect can be identified for the other bacterial species except for Escherichia coli.

Table 6. Correlations between antibacterial action and total polyphenol and flavonoid content of plant extracts.

\begin{tabular}{ccccc}
\hline & \multicolumn{2}{c}{ Polyphenol Content } & \multicolumn{2}{c}{ Flavonoid Content } \\
\hline & Pearson Index & $p$ Value & Pearson Index & $p$ Value \\
\hline White & 0.998 & $<0.01$ & 0.920 & $<0.01$ \\
Staphylococcus & 0.999 & $<0.01$ & 0.939 & $<0.01$ \\
Streptococcus mitis & 0.999 & $<0.01$ & 0.930 & $<0.01$ \\
Streptococcus sanguis & 0.999 & $<0.01$ & 0.924 & $<0.01$ \\
Enterococcus faecalis & there is no & $<0.01$ & there is no & $<0.01$ \\
Escherichia coli & correlation & & correlation & \\
\hline
\end{tabular}

\subsection{Antibacterial Effect of Experimental vs. Commercial Irrigants}

As can be seen in Figures 9-11, the best parallelism regarding the antibacterial effect was shown to be between the test solutions and the antiseptics mentioned on the strains of 
White Staphylococcus, Streptococcus mitis and Streptococcus sanguis. The highest antibacterial activity was had by the hydroalcoholic plant extract, which managed to inhibit the growth of the following bacterial strains: White Staphylococcus, Streptococcus mitis, Streptococcus sanguis and Enterococcus faecalis having the areas of inhibition (expressed in mm) of 19, 26, 26 and 12. The aqueous plant extract had no antibacterial activity; all bacterial strains developed on the disc saturated with the test solution.

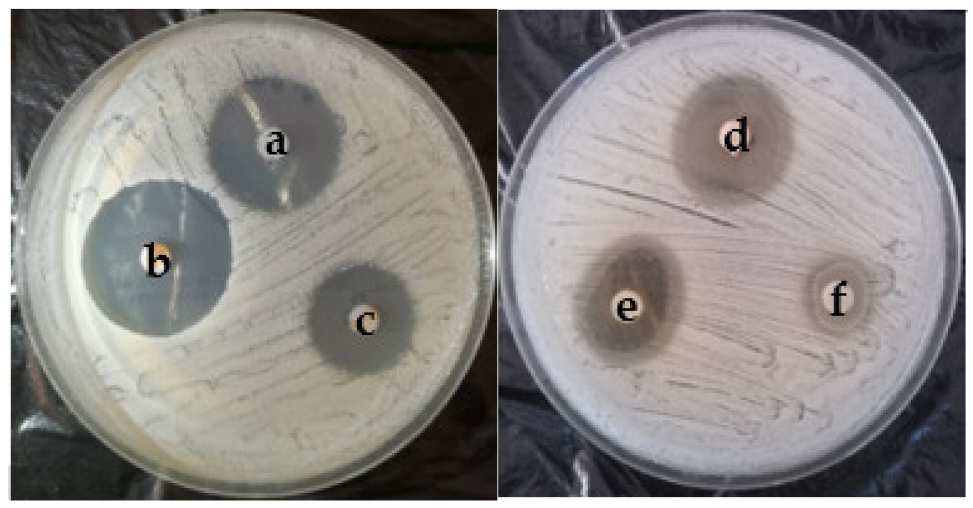

Figure 9. White Staphylococcus. (a) $\mathrm{NaOCl} 5.25 \%$; (b) $\mathrm{CHX} 2 \%$; (c) $\mathrm{NaOCl} 2 \%$; (d) hydroalcoholic vegetable extract; (e) ultrasonicated hydroalcoholic vegetable extract; (f) aqueous vegetable extract.

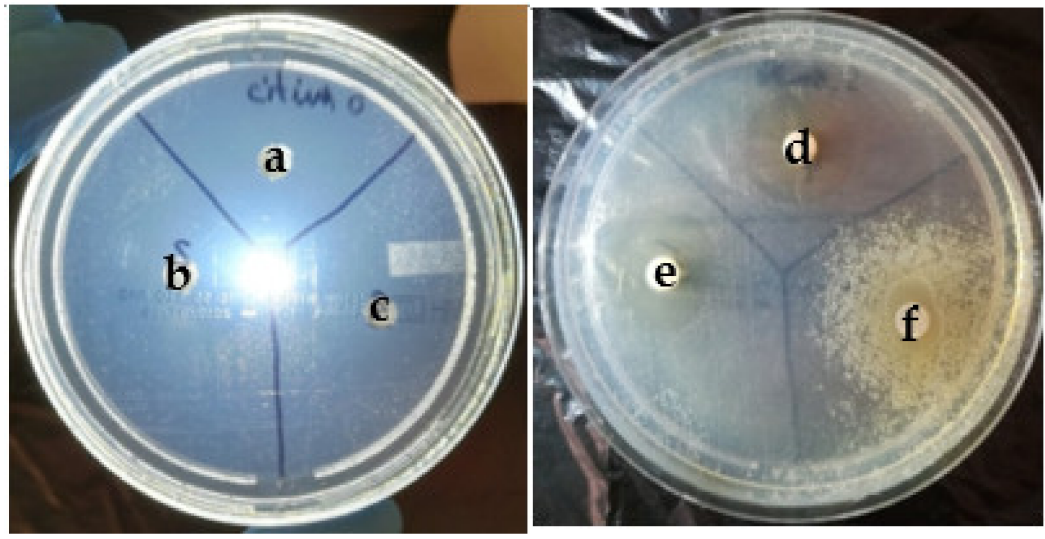

Figure 10. Streptococcus mitis. (a) $\mathrm{NaOCl} 5.25 \%$; (b) $\mathrm{CHX} \mathrm{2 \% ;} \mathrm{(c)} \mathrm{NaOCl} 2 \%$; (d) hydroalcoholic vegetable extract (e) ultrasonicated hydroalcoholic vegetable extract; (f) aqueous vegetable extract.
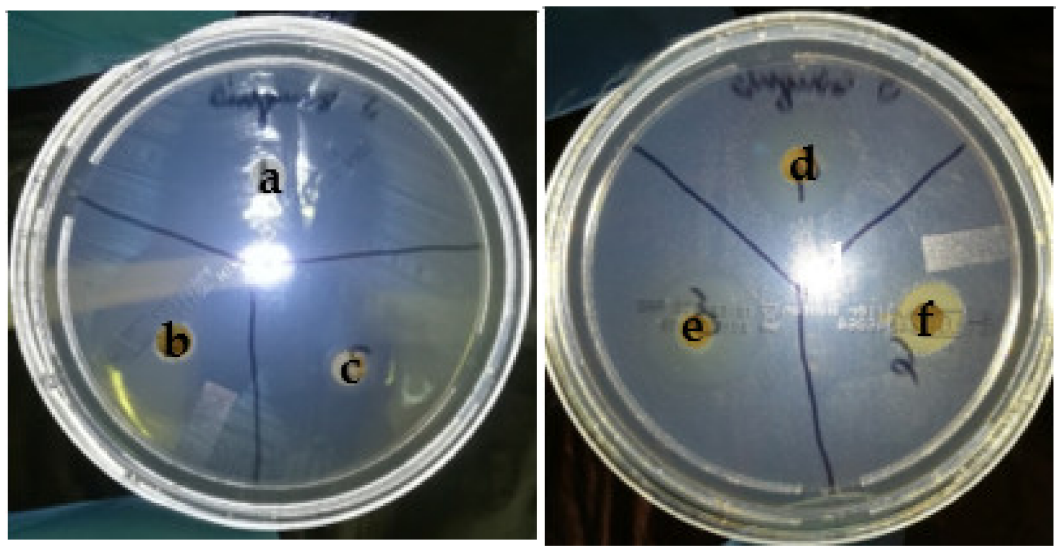

Figure 11. Streptococcus sanguis. (a) $\mathrm{NaOCl} 5.25 \%$; (b) $\mathrm{CHX} 2 \%$; (c) $\mathrm{NaOCl} 2 \%$; (d) hydroalcoholic vegetable extract; (e) ultrasonicated hydroalcoholic vegetable extract; (f) aqueous vegetable extract. 
The group of Gram-negative bacilli represented by Escherichia coli (Figure 12) showed resistance to all three types of extracts studied, noting that when reading was performed at an interval of $4 \mathrm{~h}$ after seeding the bacteria and applying test solutions, it showed an area of inhibition of $19 \mathrm{~mm}$ for the aqueous solution, an area that was initially maintained but in which resistant mutant colonies increased during the following hours.

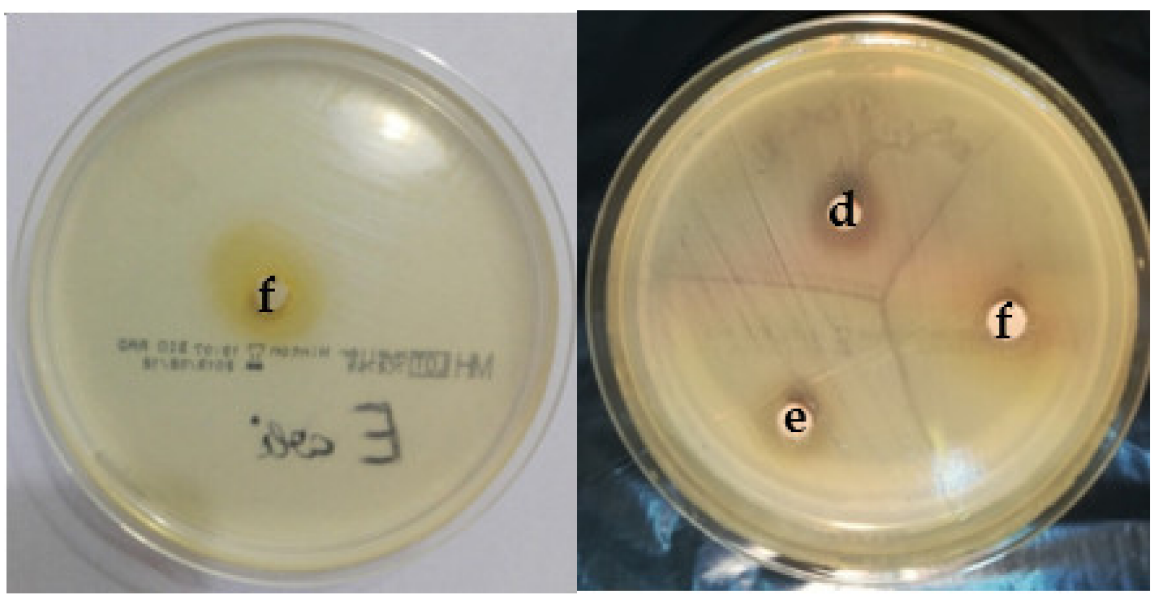

Figure 12. Escherichia coli. (d) hydroalcoholic vegetable extract; (e) ultrasonicated hydroalcoholic vegetable extract; (f) aqueous vegetable extract.

The most resistant strain was that of E. faecalis, with the mention that there is a proportionality between the level tested and those of antiseptics as seen in Figure 13; this aspect is justified by the established resistance of all strains of enterococci.

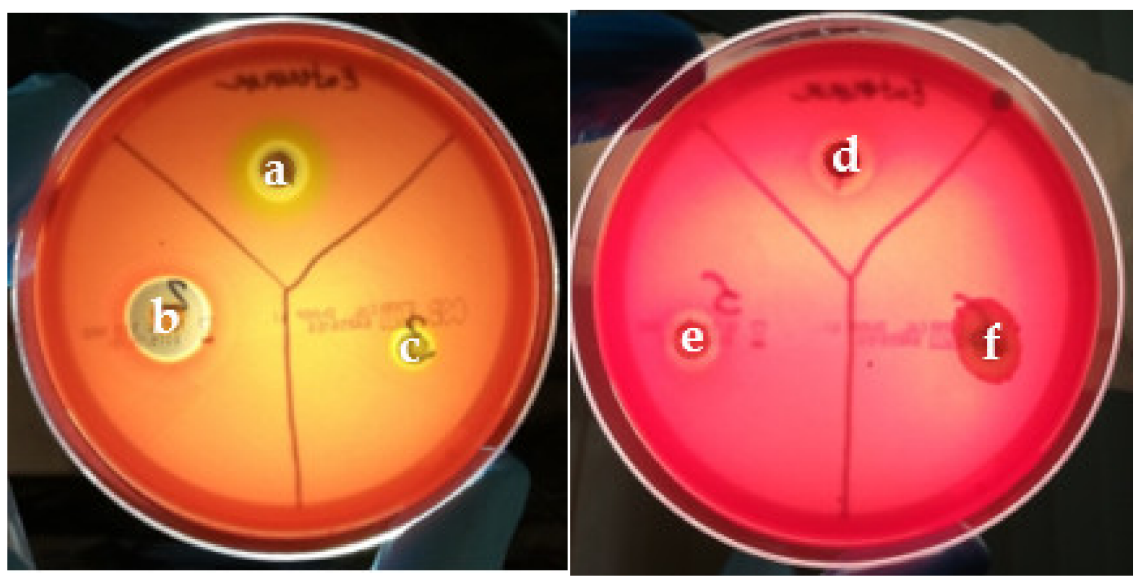

Figure 13. Enterococcus faecalis. (a) $\mathrm{NaOCl} 5.25 \%$; (b) $\mathrm{CHX} \mathrm{2 \% ;} \mathrm{(c)} \mathrm{NaOCl} 2 \%$; (d) hydroalcoholic vegetable extract; (e) ultrasonicated hydroalcoholic vegetable extract; (f) aqueous vegetable extract.

\section{Discussion}

Using the same methods of determination, UV field photo spectrometry, Remmel et al. (2012) analyzed the content of polyphenols and flavonoids of an aqueous extract of concentration $110 \mathrm{mg} / \mathrm{mL}$ of Epilobium parviflorum Schreb. with a total content of $10.45 \mathrm{Eq}$. chlorogenic acid/g vegetable powder polyphenols and $31.9 \mathrm{mg}$ EqPir/g vegetable powder flavonoids. Although difficult to compare in terms of the amount of polyphenols, because different controls were used for calibration, the data in our study show the presence of polyphenols in a higher amount in hydroalcoholic extracts than in aqueous ones because the alcohol mixed with water acquires a power of higher dissolution and ensures a better yield. Regarding the amount of flavonoids, this is higher in the study carried out by Remmel compared to the level determined in the present study from the two extracts, 
both aqueous (0.86 EqQr/g vegetable powder) and hydroalcoholic (2.87 EqQr/g vegetable powder); one of the possible reasons why it is found in larger quantities would be the temperature at which the extraction was carried out $\left(40{ }^{\circ} \mathrm{C}\right)$ and the crushing of the plant to the powder stage, thus increasing the contact surface between the plant and the solvent [33]. A very recent study (Merighi et al., 2021) used UV field photo spectrometry to analyze the content of polyphenols and flavonoids of a $40 \%$ ethanolic extract of Epilobium parviflorum Schreb. Although difficult to compare in terms of the amount of polyphenols and flavonoids, because different controls were used for calibration, the data in our study show the presence of polyphenols $(16.79 \mu \mathrm{g} / \mu \mathrm{L}$ Gallic Acid equivalent) and flavonoids ( $2.87 \mu \mathrm{g} / \mu \mathrm{L}$ Catechin equivalent) above the one founded by Merighi et al. [34].

The constituent compounds of a plant extract obtained from Epilobium parviflorum Schreb. by the method of hydrodistillation was determined in a study by Bajera et al. (2017), among which were $40 \%$ alcohols and $13.8 \%$ polyphenols, with the remaining percentages being occupied by esters, aldehydes, ketones, aromatic hydrocarbons. Although the method for determining the biologically active compounds is completely different from that of the present study, the results obtained compete with those found by Bajera who demonstrated the existence of polyphenols in the extract of Epilobium parviflorum Schreb. The results of the present study show that extracts obtained from Epilobium parviflorum Schreb. are effective on strains isolated from pathological products taken from patients with endodontic pathology, being in competition with those obtained by Bajera, although both antibacterial activity and the type of bacterial strains were achieved by different methods in the two studies [35].

The evaluation of the level of efficacy shows that there are differences between Grampositive and Gram-negative bacteria, so the strains of White Staphylococcus, Streptococcus mitis and Streptococcus sanguis proved to be the most sensitive to these extracts, maintaining that the hydroalcoholic ones were the most effective. Of all the strains tested, the hydroalcoholic extracts were the most effective, compared to the aqueous plant extracts. The lowest level of sensitivity to the tested solutions had the bacteria from the group of Gram-positive shells, specifically Enterococcus faecalis, a bacterial species with established resistance to antibiotics. There were no significant differences in antibacterial action between the hydroalcoholic and ultrasonicated extracts.

The results obtained on antibacterial susceptibility are consistent with the content of polyphenols and flavonoids, with a direct proportionality between biologically active compounds and antibacterial activity.

Although it is difficult to compare, the data in our study are consistent with those in the literature; both ethanolic extracts have antibacterial activity in direct proportion to the concentration of polyphenols and flavonoids.

The limitations of the study are given by the final number of the study group and the method for testing the antibacterial activity; to overcome these limitations for future perspectives, it is necessary to conduct a study with a larger number of patients and to extend the research using microscopy method for the antibacterial activity observations with the same high standards used in the studies conducted by Imani et al. (2020) and Li et al. (2022) [36,37].

\section{Conclusions}

All plant extracts contain polyphenols and flavonoids. Hydroalcoholic plant extract obtained from Epilobium parviflorum Schreb. had the highest quantity of polyphenols, flavonoids and antibacterial activity. The most sensitive bacterial species were those belonging to the Gram-positive group.

Author Contributions: Conceptualization, E.E.S., C.G.P. and C.B.-N.; methodology, G.R. and E.E.S.; validation, C.G.P. and C.B.-N.; formal analysis, L.L.H., C.G.P., C.B.-N., C.M.A. and M.M.; investigation, E.E.S.; resources, E.E.S.; data curation, G.R. and C.B.-N.; writing-original draft preparation, E.E.S. and C.G.P.; writing-review and editing, E.E.S., C.G.P., L.S., F.C.B., A.C., G.R., C.B.-N. and C.G.P.; 
visualization, C.G.P., E.E.S., C.B.-N. and M.M.; supervision L.S., F.C.B., A.C. and C.M.A. All authors have read and agreed to the published version of the manuscript.

Funding: This research received no external funding.

Institutional Review Board Statement: The study was conducted according to the guidelines of the Declaration of Helsinki, and approved by the Ethics Committee of "Ovidius" University (15547/09.11.2018).

Informed Consent Statement: Informed consent was obtained from all subjects involved in the study.

Conflicts of Interest: The authors declare no conflict of interest.

\section{References}

1. Vitalone, A.; Allkanjari, O. Epilobium spp: Pharmacology and phychemistry. Phytother. Res. 2018, 32, 1229-1240. [CrossRef] [PubMed]

2. Gafner, S. Herbal Drugs and Phytopharmaceuticals: A Handbook for Practice on a Scientific Basis. J. Nat. Prod. 2004, 67, 1774-1775. [CrossRef]

3. Heves, B.T.; Houghton, P.J.; Habtemariam, S.; Kéry, A. Antioxidant and antiinflammatory effect of Epilobium parviflorum Schreb. Phytother Res. 2009, 23, 719-724. [CrossRef] [PubMed]

4. Kim, J.H.; Park, K.M.; Lee, J.A. Herbal medicine for benign prostatic hyperplasia: A protocol for a systematic review of controlled trials. Medicine 2019, 98, e14023. [CrossRef]

5. Kodeš, Z.; Vrublevskaya, M.; Kulišová, M.; Jaroš, P.; Paldrychová, M.; Pádrová, K.; Lokočová, K.; Palyzová, A.; Mat'átková, O.; Kolouchová, I. Composition and Biological Activity of Vitis vinifera Winter Cane Extract on Candida Biofilm. Microorganisms 2021, 9, 2391. [CrossRef]

6. Tsao, R. Chemistry and Biochemistry of Dietary Polyphenols. Nutrients 2010, 2, 1231-1246. [CrossRef]

7. Squillaci, G.; Giorio, L.A.; Cacciola, N.A.; La Cara, F.; Morana, A. Effect of temperature and time on the phenolic extraction from grape canes. In Wastes-Solutions, Treatments and Opportunities, Wastes III; Routledge: London, UK, 2019.

8. Nagy-Bota, M.C.; Man, A.; Santacroce, L.; Brinzaniuc, K.; Pap, Z.; Pacurar, M.; Pribac, M.; Ciurea, C.N.; Pintea-Simon, I.A.; Kovacs, M. Essential Oils as Alternatives for Root-Canal Treatment and Infection Control against Enterococcus faecalis-A Preliminary Study. Appl. Sci. 2021, 11, 1422. [CrossRef]

9. Lee, D.; Im, J.; Na, H.; Ryu, S.; Yun, C.-H.; Han, S.H. The Novel Enterococcus Phage VB_EfaS_HEf13 Has Broad Lytic Activity against Clinical Isolates of Enterococcus faecalis. Front. Microbiol. 2019, 10, 2877. [CrossRef]

10. Alghamdi, F.; Shakir, M. The Influence of Enterococcus faecalis as a Dental Root Canal Pathogen on Endodontic Treat-ment: A Systematic Review. Cureus 2020, 12, e7257.

11. Amaral, R.R.; Oliveira, A.G.G.; Braga, T.; Reher, P.; de Macedo Farias, L.; Magalhães, P.P.; Ferreira, P.G.; de Souza Côrtes, M.I. Quantitative Assessment of the Efficacy of Two Different Single-File Systems in Reducing the Bacterial Load in Oval-Shaped Canals: A Clinical Study. J. Endod. 2020, 46, 1228-1234. [CrossRef]

12. Puscașu, C.G.; Caraiane, A.; Dumea, E.; Sachir, E.E.; Raftu, G.; Puscașu, R.A.; Bartok-Nicolae, C.; Cernei, E.R.; Sachelarie, L.; Hurjui, L.L. Measurement of the Clinical Effects of a Marine Fish Extract on Periodontal Healing-A Preliminary Clinical Interventional Study. Appl. Sci. 2022, 12, 677. [CrossRef]

13. Parolia, A.; Kumar, H.; Ramamurthy, S.; Madheswaran, T.; Davamani, F.; Pichika, M.R.; Mak, K.-K.; Fawzy, A.S.; Daood, U.; Pau, A. Effect of Propolis Nanoparticles against Enterococcus faecalis Biofilm in the Root Canal. Molecules 2021, 26, 715. [CrossRef] [PubMed]

14. Song, W.; Ge, S. Application of Antimicrobial Nanoparticles in Dentistry. Molecules 2019, 24, 1033. [CrossRef] [PubMed]

15. Singh, M.; Singh, S.; Salgar, A.R.; Prathibha, N.; Chandrahari, N.; Swapna, L.A. An in vitro comparative evaluation of antimicrobial efficacy of propolis, Morindacitrifolia Juice, sodium hypochlorite and chlorhexidine on Enterococcus faecalis and Candida albicans. J. Contemp. Dent. Pract. 2019, 20, 40-45.

16. Puşcaşu, C.G.; Ștefănescu, C.L.; Murineanu, R.M.; Grigorian, M.; Petcu, L.C.; Dumea, E.; Sachelarie, L.; Puşcaşu, R.A. Histological Aspects Regarding Dental Pulp of Diabetic Patients. Appl. Sci. 2021, 11, 9440. [CrossRef]

17. Jamshidi-Kia, F.; Lorigooini, Z.; Amini-Khoei, H. Medicinal plants: Past history and future perspective. J. Herbmed. Pharmacol. 2018, 7, 1-7. [CrossRef]

18. Jayaraj, A.J.; Uchimahali, J.; Gnanasundaram, T.; Thirumal, S. Evaluation of antimicrobial activity and phytochemicals analysis of whole plant extract of Vinca rosea. Evaluation 2019, 12, 132-136.

19. Arguelles-Peña, K.; Olguín-Rojas, J.A.; Acosta-Osorio, A.A.; Carrera, C.; Barbero, G.F.; García-Alvarado, M.Á.; Rodríguez-Jimenes, G.d.C. An Evaluation of the Equilibrium Properties in Hexane and Ethanol Extractive Systems for Moringa oleifera Seeds and Fatty Acid Profiles of the Extracts. Separations 2021, 8, 217. [CrossRef]

20. Darwish, W.S.; Khadr, A.E.S.; Kamel, M.A.E.N.; Abd Eldaim, M.A.; El Sayed, I.E.T.; Abdel-Bary, H.M.; Ullah, S.; Ghareeb, D.A Phytochemical Characterization and Evaluation of Biological Activities of Egyptian Carob Pods (Ceratonia siliqua L.) Aqueous Extract: In Vitro Study. Plants 2021, 10, 2626. [CrossRef] 
21. Świątek, Ł.; Sieniawska, E.; Mahomoodally, M.F.; Sadeer, N.B.; Wojtanowski, K.K.; Rajtar, B.; Polz-Dacewicz, M.; Paksoy, M.Y.; Zengin, G. Phytochemical Profile and Biological Activities of the Extracts from Two Oenanthe Species (O. aquatica and O. silaifolia). Pharmaceuticals 2022, 15, 50. [CrossRef]

22. Vilkhu, K.; Mawson, R.; Simons, L.; Bates, D. Applications and opportunities for ul-trasound assisted extraction in the food industry-A review. Innov. Food Sci. Emerg. Technol. 2008, 9, 161-169. [CrossRef]

23. Vinatoru, M. An overview of the ultrasonically assisted extraction of bioactive principles from herbs. Ultrason. Sonochem. 2001, 8, 303-313. [CrossRef]

24. Hromàdkovà, Z.; Ebringerovà, A. Ultrasonic extraction of plant materials-investigation of hemicellulose release from buckwheat hulls. Ultrason. Sonochem. 2003, 10, 127-133.

25. EDQM. European Pharmacopoeia, 9th ed.; European Pharmacopoeia, Council of Europe, B.P. 907, F-67029; EDQM: Strasbourg, France, 2016.

26. Shami, A.M.M.; Philip, K.; Muniady, S. Synergy of antibacterial and antioxidant activities from crude extracts and peptides of selected plant mixture. BMC Complementary Altern. Med. 2013, 13, 360. [CrossRef] [PubMed]

27. El-Mahrouk, M.E.; Dewir, Y.H. Physico-Chemical Properties of Compost Based Waste-Recycling of Grape Fruit as Nursery Growing Medium. Am. J. Plant Sci. 2016, 7, 48-54. [CrossRef]

28. Gabriel, A.; Joe, V.; Patrick, E.D. Folin-Ciocalteau Reagent for Polyphenolic Assay. IJFS 2014, 3, $147-156$.

29. Adamiak, K.; Kurzawa, M.; Sionkowska, A. Physicochemical Performance of Collagen Modified by Melissa officinalis Extract. Cosmetics 2021, 8, 95. [CrossRef]

30. Gaire, U.; Thapa Shrestha, U.; Adhikari, S.; Adhikari, N.; Bastola, A.; Rijal, K.R.; Ghimire, P.; Banjara, M.R. Antibiotic Susceptibility, Biofilm Production, and Detection of mecA Gene among Staphylococcus aureus Isolates from Different Clinical Specimens. Diseases 2021, 9, 80. [CrossRef]

31. Contreras-Alvarado, L.M.; Zavala-Vega, S.; Cruz-Córdova, A.; Reyes-Grajeda, J.P.; Escalona-Venegas, G.; Flores, V.; Alcázar-López, V.; Arellano-Galindo, J.; Hernández-Castro, R.; Castro-Escarpulli, G.; et al. Molecular Epidemiology of Multidrug-Resistant Uropathogenic Escherichia coli O25b Strains Associated with Complicated Urinary Tract Infection in Children. Microorganisms 2021, 9, 2299. [CrossRef]

32. Buiuc, D.; Neguț, M. Tratat de Microbiologieclinică, 3rd ed.; EdituraMedicală: Bucharest, Romania, 2017.

33. Remmel, I.; Lauri, V.; Lauri, T.; Vallo, M.; Ain, R. Phenolic Compounds in Five Epilobium Species Collected from Estonia. Nat. Prod. Commun. 2012, 7, 1323-1324. [CrossRef]

34. Merighi, S.; Travagli, A.; Tedeschi, P.; Marchetti, N.; Gessi, S. Antioxidant and Antiinflammatory Effects of Epilobium parviflorum, Melilotus officinalis and Cardiospermum halicacabum Plant Extracts in Macrophage and Microglial Cells. Cells 2021, $10,2691$. [CrossRef] [PubMed]

35. Bajer, T.; Šilha, D.; Karel, V.; Bajerová, P. Composition and antimicrobial activity of the essential oil, distilled aromatic water and herbal infusion from Epilobium parviflorum Schreb. Ind. Crops Prod. 2017, 100, 95-105. [CrossRef]

36. Li, Y.; Liu, Y.; Yao, B.; Narasimalu, S.; Dong, Z. Rapid preparation and antimicrobial activity of polyurea coatings with RE-Doped nano-ZnO. Microb. Biotechnol. 2022, 15, 548-560. [CrossRef] [PubMed]

37. Imani, S.M.; Ladouceur, L.; Marshall, T.; Maclachlan, R.; Soleymani, L.; Didar, T.F. Antimicrobial Nanomaterials and Coatings: Current Mechanisms and Future Perspectives to Control the Spread of Viruses Including SARS-CoV-2ACS. Nano 2020, 14, 12341-12369. [CrossRef] [PubMed] 